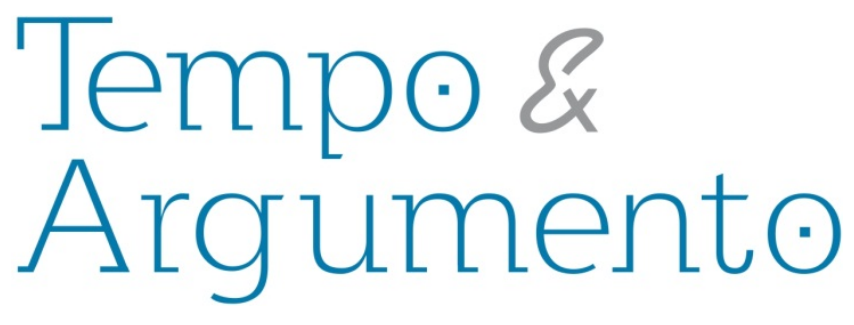

\title{
Ditadura, Democracia e Esquecimento: \\ 1964 - o acontecimento recalcado e a ascensão do Jornal Folha de São Paulo como canal da democracia
}

\begin{abstract}
Resumo
Este artigo pretende refletir sobre como o Golpe de 1964 a partir da maneira como o jornal Folha de São Paulo viu e narrou o processo de abertura política entre 1978 e 1980. A intenção é compreender como o periódico conseguiu construir uma identidade vinculada às expectativas de democracia, ao mesmo tempo em que formulou um dos mais bem-sucedidos projetos de "reconstrução" da memória do Brasil contemporâneo. O objetivo aqui é discutir suas estratégias de ação a fim de conferir como alguns grupos conseguem $\mathrm{o}$ equilíbrio entre memória $\mathrm{e}$ esquecimento na efetivação uma identidade política desejável.
\end{abstract}

\section{Sônia Meneses}

Doutora em História pela Universidade Federal Fluminense UFF. Professora da Universidade Regional do Cariri - URCA. Atua na área de teoria da história e história cultural, pesquisas com interesse no tempo presente, história e mídia, história e política sonia.urca@gmail.com

Palavras-chave: Democracia. Ditadura. Esquecimento. Folha de São Paulo. Brasil - História - Golpe Militar 1964.

\section{Para citar este artigo:}

MENESES, Sônia. Ditadura, democracia e esquecimento: 1964 - o acontecimento recalcado e a ascensão do Jornal Folha de São Paulo como canal da democracia. Revista Tempo e Argumento, Florianópolis, v. 5, n.10, jul./dez. 2013. p. 39 - 71. 
Dictatorship, Democracy and Forgetting: 1964 - The event repressed and the emergence of the newspaper Folha de São Paulo as the channel of democracy

\begin{abstract}
This paper reflects on how the coup of 1964 was narrated by the newspaper Folha de São Paulo from the process of political opening, between 1978-1980. The intention is to understand how the newspaper was able to build an identity linked to expectations of democracy, while it made one of the most successful projects of "reconstruction" of memory in contemporary Brazil. He discusses strategies in order to understand how some groups balanced memory and forgetting in effecting a political identity desirable.
\end{abstract}

Keywords: Democracy. Dictatorship. Forgetting. Folha de São Paulo. 
Naquela noite, Maria Teresa escolheu um vestido azul-piscina e optou por prender os cabelos negros no alto da cabeça. Quando subiu ao pequeno palanque de 1,60 metros de altura postado na praça da República, em frente à Central do Brasil, no Rio de Janeiro, fez-se silêncio entre os 100 mil presentes. Eram 19 h 44 de 13 de março de 1964. Ela ainda não sabia, mas, aos 24 anos, a primeira-dama mais bonita que 0 país já teve participava do primeiro e último comício ao lado do marido, João Belchior Marques Goulart, 20 anos mais velho. Dezoito dias depois daquela noite, o presidente João Goulart, o Jango, seria apeado do poder por um golpe de generais que daria início à ditadura militar que vigeu (sic) até 1985 (DÁVILA, 2004).

É a com a imagem de Maria Teresa, esposa do então presidente João Goulart, que o jornalista Sérgio Dávila começa seu artigo de reflexão sobre os dias que antecederam o Golpe de 1964. Ao tempo em que busca construir um ponto de partida retrospectivo sobre as ações que colaboraram para sua efetivação, o jornalista nos coloca quase como observadores de uma cena instauradora, claramente carregada de dramaticidade. Nela estão mobilizados o passado, o futuro e o presente. O jornalista é a voz a se pronunciar a partir de um tempo exterior ao da situação narrada. Pode-se perceber, pelo cruzamento temporal presente em seu texto, que antecipa acontecimentos posteriores àquele dia. A matéria foi apresentada em uma série de reportagens nas quais o jornal, em 2004, organizou o caderno especial "40 anos do Golpe".

O discurso da Central do Brasil, realizado em 13 de maio de 1964, é apresentado pelo jornalista como o marco referencial para os acontecimentos que culminaram, dias depois, com a tomada do poder pelo militares. Certamente, não é apontado como único, porém, é tomado como deflagrador importante dos eventos que ajudam a compor a linha de causas e efeitos que culminaram com o 31 de março e a sucessão de ocorrências em 21 anos de regime militar. A partir da narrativa, as pessoas presentes ao comício da Central do Brasil são as testemunhas de um acontecimento que marcaria o final de uma etapa da política brasileira. É o que o jornalista, logo em seguida, destaca em seu texto: 
A face mais evidente da reação, porém, viria seis dias depois. Apoiadas pela UDN, pelos governadores Adhemar de Barros (SP) e Carlos Lacerda e outras lideranças conservadoras, organizações católicas levaram 500 mil pessoas às ruas de São Paulo $-10 \%$ da população da cidade à época-, em sua maioria de classe média. Era a Marcha da Família, com Deus, pela Liberdade, importante por mostrar aos militares que conspiravam que também eles tinham potencial apoio popular. Seria o próximo lance do xadrez político que levaria ao golpe do dia 31 de março de 1964 (DÁVILA, 2004).

Dávila parte do lugar de quem já conhece o futuro do passado e o agenciamento de sentidos sobre os eventos que eclodiram naqueles dias. Dispô-los em um tabuleiro de xadrez marca exatamente a maneira teatral do arranjo daquelas posições em sua narrativa. Para a composição da trama, utiliza-se da reflexão realizada em inúmeras obras historiográficas, midiáticas e depoimentos que, em 2004, já haviam construído um complexo panorama de explicação sobre aqueles dias. Há um processo de sistematização do evento que o toma de maneira retrospectiva a partir de um encadeamento linear de significações. Em seu texto a evocação de Maria Teresa pode ser lida também como a inflexão entre dois momentos temporais distintos: um antes e um depois daquele dia. Segundo Dávila (2004), citando o historiador brasilianista Thomas Skidmore, na mesma matéria, "a presença de Jango com ela foi entendida como um recado ao país de que ele estava tomando o comando". Naquele presente-passado, sobre o "pequeno palanque de 1,60 metros de altura", a imagem da bela esposa e seu marido contrapõe o sentimento de tensão parecendo insinuar que o rumo dos acontecimentos poderia ter sido outro. Embora Dávila destaque "que segundo alguns historiadores, o golpe viria de qualquer maneira", sendo o comício apenas seu elemento de precipitação, em sua narrativa, João Goulart e Maria Teresa são apresentados como o espectro das esperanças postas em cena naquele momento e eram amparados pelas propaladas reformas de base. Mas a cena pode ser também percebida como a última imagem melancólica de um tempo que parecia se encerrar ali. Um tempo que o próprio jornal Folha de São Paulo à época ajudou a construir como de incertezas, angústias e ansiedades, o que pode ser percebido em algumas manchetes dos dias que antecederam ao comício: 


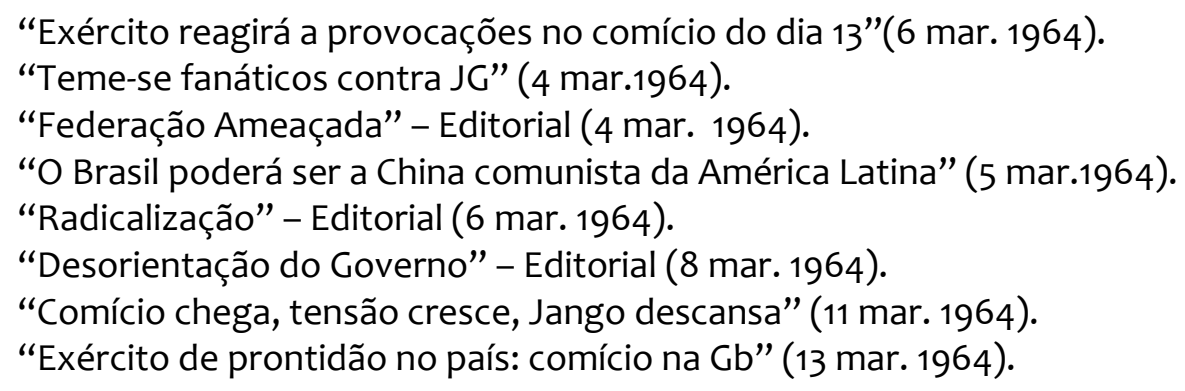

Quando se vislumbram tais episódios sob o olhar da rememoração, seja ela midiática ou historiográfica, a visão que oferecem é como se fizessem parte de um evento completo, aparentemente formulado em todos os meandros: fatos e acontecimentos como atos de linguagem. Dessa forma, o golpe de 1964 transporta uma carga semântica e conceitual que o situa como marco indelével para a história recente do País, o que concede a ele o estatuto de acontecimento histórico exemplar. Não obstante, 49 anos antes o que predominava era a dialética entre uma necessidade de previsão e o confronto com o inesperado. O tempo da escritura de vários eventos; várias novidades dispostas em cena pública. Ocorrências que se seguiam umas às outras em uma cadeia lancinante que, por vezes, instauravam dramáticos instantes de rupturas, ou, como chama à atenção Ricoeur (1991, p. 42), instantes que eclodiam e acabavam por alterar rotinas e padrões estabelecidos, impondo novas demandas de sentidos.

Observa-se um movimento frenético no qual entravam em cena as articulações políticas e sociais dos vários grupos que ali transitavam e as necessidades de explicação sobre as ocorrências consequentes àquelas ações. É possível identificar, nesse enredamento imediato, várias linhas a se cruzar, a saber: os arquétipos do cotidiano, , os tipos de agenciamentos de sentido aos quais eram submetidas as disputas de divulgação e, por fim, sua escritura, que lhes dava o formato de notícias. Diante dessa tensão, elementos de explicação eram colocados em ação naquilo que, posteriormente, foi agregado no grande amálgama do qual o golpe de 1964 se tornou a síntese. Partindo dessa configuração, o episódio se tornou artefato histórico sobre o qual se aprofundam disputas de versões. Rejeitado e/ou celebrado, o acontecimento assume lugar de uma 
inscrição histórica, apresentando seu potencial como agenciador de sentidos históricos, marcos de memória e ações de esquecimento.

Para o jornal Folha de São Paulo, 1964 foi inicialmente celebrado e formulado como ocorrência exemplar e positiva1, narrado como "Revolução" necessária, imediatamente associada a outros eventos, de forma a conceder-lhe densidade histórica. Em sua primeira fase narrativa - período que vai de 1964 a 1975 -, o acontecimento é celebrado de forma efusiva pelo jornal, como tendo sido o evento marcante que recolocou o País no "rumo" certo como pode ser visto no editorial de 3 de abril de 1964:

Voltou a nação, felizmente, ao regime de plena legalidade que se achava praticamente suprimido nos últimos tempos do governo do expresidente João Goulart. E isso se fez, nota-se, com o mínimo traumatismo, graças ao discernimento de nossas forças armadas para conter os desmandos de um político que, cercado de assessores comunistas, procurava manobrar o país. (Editorial - O Brasil, 1964, p. 3)

Entretanto, na dinâmica de relações em que as versões são constantemente postas em disputa, narrativas e situações que antes predominavam são colocadas em xeque por outras que Ihes disputavam o lugar. Em fins de 70, ganham visibilidade as reclamações por mudanças no cenário político, destacando-se o processo de abertura política e, posteriormente, a luta pelas eleições diretas na primeira metade dos anos 80. Tal elemento ressalta a dimensão ideológica presente nessa produção; uma dimensão nem sempre visível, que quase sempre "permanece dissimulada; ]...] inconfessável; mascara-se ao se transformar em denúncia contra os adversários no campo das competições entre ideologias" (RICOEUR, 2007, p. 97).

Tais exigências enfraqueciam claramente os grupos políticos que tinham dominando até ali. Para muitos que se haviam beneficiado com o episódio, começavam a desmoronar a aura de positividade do acontecimento e a certeza de um futuro promissor relacionado a ele. O futuro agora dependia de que ele fosse definitivamente encerrado enquanto experiência e permitisse a emergência de novos horizontes de expectativa.

\footnotetext{
${ }^{1} \mathrm{O}$ aprofundamento desse argumento encontra-se em minha tese de doutorado: Meneses, Sônia. A Operação Midiográfica - A produção de acontecimentos e conhecimentos históricos através dos meios de comunicação - A Folha de São Paulo e o Golpe de 1964. Niterói-RJ Universidade Federal Fluminense, 2011. End. para acesso: http://www.historia.uff.br/stricto/td/1296.pdf.
} 
Mais do que isso, era preciso que se construísse, ou que se realçasse uma nova memória histórica sobre ele.

\section{"Ventilai as consciências": o episódio Diaféria e a preparação para a anistia}

Entre 1977 e 1985, o foco se dará sobre fechamento do ciclo acontecimental relacionado a 1964. Para muitos, não interessava interrogar quem havia auxiliado ou tivesse sido responsável por sua efetivação, mas quem se engajaria na mudança. $A$ euforia produzida em torno dos debates pela abertura e, posteriormente, sobre o movimento das Diretas eclipsará durante longos anos a memória em torno dos momentos da efetivação do golpe, seu desenrolar atrelado às denúncias de torturas, perseguições políticas e exílios. Ficaram à sombra boa parte de seus deflagradores e apoiadores, a tal ponto que alguns se tornaram os porta-vozes da luta pela democracia, como foi o caso do jornal aqui analisado, a Folha de São Paulo. Cabe questionar: como um dos principais apoiadores dos militares conseguiu reformular esta imagem a ponto de ser visto como um canal da democracia e opositor histórico ao golpe em um espaço tão curto de tempo?

Para começar a pensar sobre a pergunta, consideremos dois desafios a serem enfrentados pelo jornal em fins de 1970: primeiro, a tarefa de formular sua desvinculação pública do evento; segundo, a elaboração de uma identidade que o apresentasse como um diferencial em meio à diversidade discursiva daqueles dias. Ou seja, estava em jogo a construção de novos marcos memoráveis para substituir a imagem do jornal ligada aos militares. No dia 15 de setembro de 1977, o inesperado parece conceder ao jornal a fresta pela qual poderia escapar do enredo que ajudara a escrever anos antes. Vejamos:

O jornalista Lourenço Diaféria da "Folha" foi detido ontem em sua casa por volta das 17 horas por agentes da política federal. [...] Na última sexta-feira, atendendo à representação do ministro do Exército General Sílvio Frota, o ministro determinou a abertura de inquérito para o enquadramento de Lourenço Diaféria na Lei de Segurança Nacional em virtude de uma crônica que publicou nesse jornal, no dia $1^{\circ}$ desse mês (PRESO, 1977). 
Lourenço Diaféria, conhecido cronista da Folha, há uma década trabalhava no jornal escrevendo sobre o cotidiano e a cidade de São Paulo. Porém, no dia $1^{\circ}$ de setembro de 1977, ao escrever uma crônica na qual elogiava a figura de um sargento que salvara a vida de uma criança, ressaltara a imagem do militar, construído como o herói de sua narrativa cotidiana, mas escorregou por uma crítica à hierarquia militar que disputava o poder naquele momento. Em texto intitulado: “Herói. Morto. Nós”, Diaféria, exaltava o sargento, dizendo:

[... Prefiro esse sargento herói ao duque de Caxias. O duque de Caxias é um homem a cavalo reduzido a uma estátua. Aquela espada que o duque ergue ao ar aqui na Praça Princesa Isabel - onde se reúnem os ciganos e as pombas do entardecer - oxidou-se no coração do povo. O povo está cansado de espadas e de cavalos. O povo urina nos heróis de pedestal. Ao povo desgosta o herói de bronze, irretocável e irretorquível, como as enfadonhas lições repetidas por cansadas professoras que não acreditam no que mandam decorar (DIAFÉRIA, 1977).

O texto do jornalista foi o estopim que aprofundou a crise entre a Folha e os militares. A situação começara a se desenrolar com a morte do jornalista Vladimir Herzog nas dependências do DOI-CODI em outubro de 1975 e levaria o jornal a começar a se afastar do episódio iniciando uma nova fase na construção de sua identidade política. A crônica demonstra ainda como a frustração sobre as ações dos militares ganhava peso nas páginas do jornal. Mesmo que não tivesse tido a expressividade política de outros artigos e matérias publicados em jornais nos anos anteriores contra o regime (MOLICA, 2005), ajudou a instaurar um ponto de ruptura visível entre a Folha e os militares.

Sua crônica atacava três aspectos capitais naquela conjuntura: a imagem do herói atrelada à figura distante de Duque de Caxias, que representava a hierarquia militar no comando no País; o descontentamento popular diante de um poder “oxidado" e, por fim, o papel da história ensinada para reverenciar esse poder. Embora tivesse sido uma crítica contundente, não foi exatamente a matéria que instaurou o ponto de ruptura entre a Folha e o governo militar, mas o que se produziu a partir dela. No dia 16 de setembro, em lugar da crônica de Diaféria, uma nota da redação explicava que "a crônica diária de Lourenço Diaféria deixa de ser publicada em virtude de o cronista ter sido detido 
às $17 \mathrm{~h}$ de ontem pela Polícia Federal conforme noticiamos na Primeira Página” (COLUNA, 1977).

A partir da publicação da coluna em branco, o jornal passa a sofrer fortes pressões dos militares para que recuasse em sua posição, o que de fato ocorre em parte, com Otávio Frias deixando definitivamente a chefia da direção no dia 19 do mesmo mês, assumindo no dia seguinte, em seu lugar, Boris Casoy. Embora deixe de publicar editoriais até 1978, nos dias seguintes o episódio ganha expressividade nas páginas do jornal, sendo alimentado cotidianamente por novas matérias como pode ser constado em algumas manchetes:

"Nós" (editorial do dia 17 de setembro no qual o jornal se posiciona sobre o episódio);

"Advogado faz visita a Diaféria (17/09/1977);

"Montoro critica, Rezende defende" (idem);

"As declarações do cardeal Arns" (idem);

"ABI manifesta sua preocupação" (idem);

“Lourenço Diaféria presta depoimento" (18/09/1977);

"Suspensas visitas a Diaféria (19/09/1977);

“Juiz decide hoje sobre prisão de Diaféria" (20 set. 1977).

O último editorial escrito nessa fase é justamente “Nós" (1977), no qual o jornal se posiciona de forma contundente sobre o episódio e sobre "os serviços que prestou e está prestando ao Brasil” naquele momento e faz questão de mencionar a grande comoção e solidariedade dos outros veículos à Folha.

Quando a coluna de Diaféria é publicada em branco no dia 16 de setembro, o acontecimento ganha visibilidade e uma audiência cada vez maior, sobretudo porque gera um novo fluxo de notícias, cotidianamente alimentadas tanto pela Folha como por outros jornais que também aproveitam seu potencial mobilizador para agregar reivindicação por mudanças no cenário político. Sendo assim, o espaço em branco irrompe como a novidade que, simbolicamente, cria um momento de inconteste tensão pública entre o jornal e os militares e ajuda a formular ainda outro importante elemento: a condição de vítima para a Folha, que, agora, também podia narrar-se como veículo que havia sido perseguido e censurado pelo regime, conforme podiam atestar as manchetes daqueles dias. O episódio Diaféria foi, assim, inscrito na história do jornal: 
Na manhã do dia 16 de setembro de 1977, os leitores da Folha receberam o jornal com uma longa coluna em branco, de cima a baixo, no canto direito da última página da "llustrada". No alto, como de hábito, estava escrito o nome do colunista: Lourenço Diaféria. [...] Começava aí a mais grave crise que a Folha viveria com o regime militar (1964-85) (MAGALHÃES, 2001).

O trecho acima foi extraído do artigo produzido para um suplemento especial publicado no site da Folha Online em 2001, em comemoração aos 80 anos do jornal. $\mathrm{Na}$ seção sob o título: “militares ameaçam suspender circulação”, o jornalista Mário Magalhães, cujo artigo foi intitulado "Militares ameaçam suspender circulação - Folha apoiou o regime de 64, mas se engajou na redemocratização nos anos 70", realizava uma análise que, em certo sentido, resumia o processo de ressignificação da memória e construção de identidade articulado pelo diário e plenamente configurado nos anos 90.

Não por acaso, o artigo é o primeiro texto apresentado após um relato no qual é narrada, em ordem cronológica, a história do jornal até sua aquisição definitiva pelo grupo Frias-Caldeira em 1962 e sua expansão mercadológica nos anos 80. Em sua narrativa de retrospecção, o período que vai de 1962 a 1977, a posição política do jornal é apresentada de maneira hesitante e dúbia, reforçando a tese de boa parte da grande mídia, segundo a qual não havia muito a fazer naquele período diante da censura, tampouco clareza frente ao episódio deflagrado em 1964 - golpe? revolução? -, minimizando, assim, a atuação do veículo em relação aos eventos de março e abril daquele ano, conforme demonstram outros trechos do artigo:

A Folha apoiou a deposição de João Goulart, mas não participou de nenhuma conspiração" [...].(MAGALHÃES, 2001)

[...] Quando os militares tomaram o poder, a Folha tinha dois colunistas políticos (além de Hermano Alves, D’Alembert Jaccoud escrevia de Brasília). Na página 4, ao lado dos editoriais, revezavam-se Cecília Meirelles e Carlos Heitor Cony. Nos anos seguintes, o jornal se pautaria por uma preocupação, a retomada da agenda democrática, antecipada na manchete de 3 de abril de 1964: "Lacerda propõe: eleição já do novo presidente" [...].(MAGALHÃES, 2001)

Embora Magalhães não apague os rastros que ligariam a Folha ao golpe, ressignifica sua importância no conjunto das novas ocorrências que se seguiram em fins 
dos anos 70. Opera uma estratégia de esquecimento a partir de uma nova leitura sobre os episódios desencadeados naqueles dias e na formulação de uma nova identidade para o grupo. O passado é reconfigurado para produzir um afastamento quase cirúrgico do jornal em relação ao evento e aos militares. Ao fazer isso, realiza uma clara seleção dos elementos, de maneira a fazer crer que nunca houve um apoio efetivo do jornal aos acontecimentos de 1964, posto que;

A Folha era ainda um diário pequeno, num mercado liderado com folga por "O Estado de S. Paulo". A preocupação essencial dos seus donos, Octavio Frias de Oliveira e Carlos Caldeira Filho, era com a saúde financeira do jornal que haviam comprado em 1962. (MAGALHÃES, 2001)

Dentro dessa lógica, outros trechos, muito mais numerosos e enfáticos de apoio do jornal ao evento, são omitidos dando lugar a outra lembrança, ou, mais precisamente, àquilo que Ricoeur denominou de "lembrança encobridora”, que funciona "tanto na escala da vida coletiva como na da psicologia da vida cotidiana, por meio da exaltação do acontecimento da libertação" (RICOEUR, 2007, p. 457).

Dessa forma, setembro de 1977 é tomado como o marco do rompimento público do jornal com o governo militar. O caso Diaféria, seu acontecimento de libertação. A coluna em branco funciona, implicitamente, como a quebra de um contrato simbólico entre veículo e o evento, que agora entrará em um novo ciclo de significação para o periódico.

Para Abramo, o caso Diaféria serviu como o estopim que precipitou seu desligamento, já esperado, da redação do jornal. Diz o jornalista: “No dia seguinte o general Hugo Abreu, chefe da casa civil de Geisel, ligou para o jornal e Frias pediu que me demitisse; e me demiti. Ele não me demitiu, pediu que eu o fizesse" (ABRAMO, 1988, p. 90). Em sua opinião, o projeto de distensão do regime pedia "um acordo tácito entre os militares e os donos dos jornais. Creio que eles não chegaram a falar abertamente no assunto [...]. Subitamente, num prazo de dois ou três anos, fomos quase todos eliminados" (ABRAMO, 1988, p. 90).

Considerando as reflexões de Abramo como um dos componentes relevantes naquela conjuntura, o papel desempenhado por esse episódio na elaboração da história 

deveria ser lembrando.

No complexo amálgama de ocorrências desencadeadas em fins de 70, mesmo que a prisão de Diaféria não tivesse produzido grande efeito político em um momento no qual eram comuns as represálias dos militares a órgãos da impressa e a jornalistas, como foi o escandaloso caso de Vladimir Herzog, o episódio reveste-se de significância emancipadora e imprime um momento visível para o distanciamento e ajuda a construir uma relação de alteridade entre a Folha e os militares. Percebe-se, nesse ponto, uma virada na relação memória/esquecimento e construção de identidade. Todo o esforço realizado na produção de uma memória instrumentalizada sobre o evento, ou um exercício abusivo de memória com a evocação insistente do episódio a fim de firmá-lo como ocorrência positiva para história da nação, agora se revertia em esforço de esquecimento, o que atesta que toda a formulação da nova identidade se ampara na função mediadora e seletiva da narrativa, fazendo com que os abusos de memória se tornassem, consequentemente, abusos de esquecimento.

Com isso, o jornal começa a estruturar um bem-sucedido projeto de reconstrução de sua imagem pública e sobre a memória de sua participação nos eventos em que, poucos anos antes, havia desempenhado um papel capital como apoiador. Antecipa-se, capturando para si a luta pela democracia e pela abertura política, numa estratégia de esquecimento que priva e controla narrativas autorizadas a partir dos conteúdos divulgados em suas páginas. Abrir-se para as diversas vozes era uma maneira dissimulada de tornar-se o lugar autorizado de onde elas deviam partir. Melhor ter exilados, presos políticos e intelectuais falando de dentro do jornal do que de fora dele.

Ainda no final daquele mês de setembro de 1977, Hermes Lima² escrevia para a Secção Tendência/Debates um texto bastante significativo sobre os novos rumos tomados pelo jornal a partir daquele episódio:

\footnotetext{
${ }^{2}$ Foi presidente do Supremo Tribunal Federal, membro da Academia Brasileira de Letras, ministro-chefe do
} 
A sociedade civil é basicamente de paisanas, aqui e em toda a parte. A paisanada é que escreve poesia, romance e filosofia. Também produz, discute, briga e protesta. Aparentemente é indisciplinada. Anda sempre fora de forma. Mas é o chão em que o Estado deita raízes (LIMA, 1967).

A sociedade civil agora figura como o elemento de destaque. É em seu nome que o jornal passa a falar na nova conjuntura política. Não por acaso, exatamente no mês em que se instaura abertamente o ponto de tensão entre militares e o jornal, começam a ser publicados os textos mais contundentes de crítica ao regime. Percebamos que agora sociedade civil e governo militar, que antes eram apresentados como os elos complementares dessa sociedade, passam a ser projetados na cena pública quase como polos opostos.

Civicamente estamos paralisados. Partidos sob vigilância, censura de livros, controle da juventude universitária. Proibição dos comícios, das manifestações públicas [...]. Revestiu-se assim o Estado de uma armadura autoritária que o afasta da sociedade civil (LIMA, 1967).

\section{Como destaca Ruy Lopes:}

Aproveitando os ventos liberalizantes que então sopravam, a Folha lançou-se ao novo projeto, que aí está, a vista de todos. Passou a emitir opinião diariamente, contratou comentaristas políticos, ampliou a editoria específica e abriu espaço para que as figuras mais eminentes da comunidade - independentemente de suas convicções ideológicas abordassem temas da atualidade sem qualquer interferência da direção do jornal. Graças a isto, a Folha que já tinha uma grande circulação, aumentou seu peso político, tornando-se hoje leitura obrigatória nos centros de decisão. A postura política transformou o boletim em um órgão influente (apud MOTA; CAPELATO, 1981, p213).

A posição de Ruy Lopes, assim como o artigo de Mário Magalhães, acusa as estratégias desse esquecimento administrado a partir da função seletiva da narrativa. Se, para muitos, 1964, desde o princípio, fora apresentado como o ano da tomada de poder autoritária que instituiu a ditadura no País, para a Folha e outros grupos que o haviam apoiado é somente no final de 70 que tal explicação passa a ser considerada no horizonte

Gabinete Civil da Presidência da República de 8 de setembro de 1961 a 18 de setembro de 1962, e primeiro-ministro do Brasil durante a breve experiência parlamentarista ocorrida no governo João Goulart. 
de significação do episódio. Na nova fase, o passado deixa de oferecer lições positivas para o presente e torna-se confuso; perde sua força mobilizadora para o futuro, que também se torna um tempo de incerteza.

O lento processo de distensão política foi uma preparação para o esquecimento, não somente sobre as ações do jornal, mas dos demais grupos civis que apoiaram o golpe, tornando-se o momento para que a Folha requeresse para si a graça anistiante. O presente, nesse momento, dispensava o passado e preferia falar diretamente ao futuro, como se tudo se eclipsasse frente aos "ventos liberalizantes que então sobravam".

\section{O acontecimento recalcado e a ascensão da Folha como canal da democracia}

A ampliação da área de influência da Folha entre o público pode ter como marco inicial o processo de abertura política do regime militar, nos meados de 70. [...] A partir de então, a Folha passou a ser identificada como um jornal de resistência ao regime autoritário e uma espécie de "porta voz" da chamada "sociedade civil". A direção da empresa teve a sensibilidade de perceber que o país mudava e apostou num ramo que, o futuro comprovaria, era o que a maior parte dos brasileiros desejava seguir (SILVA, 2005, 54).

Com o mesmo engajamento com que a Folha se abriu em 1964 para os eventos que precipitaram o golpe, defendendo-os, nos 15 anos seguintes seu discurso passa a assumir um papel recorrente em defesa da democracia e da abertura política em fins de 70. Na construção narrativa sobre sua mudança frente ao episódio, é assim que o jornalista Carlos Eduardo Lins da Silva ${ }^{3}$ narra a mudança do jornal: prefere explicar que tal direcionamento se deu pela percepção da empresa sobre o fato de que o Brasil mudava, apostando em tal elemento.

\footnotetext{
${ }^{3}$ Carlos Eduardo Lins da Silva é um dos mais importantes personagens na história recente do Jornal Folha de São Paulo. Jornalista engajado, assumiu diversos postos, desde correspondente internacional, ombudsman, diretor de redação, além de ter tido um papel capital tanto na concepção como na implantação do projeto Folha. Boa parte dessa experiência é relatada na obra Mil Dias, reeditada anos depois como Mil Dias: seis mil dias Depois pela Publifolha, em 2005.
} 
Dessa forma, o presente, tempo no qual o jornalista exercita sua reflexão dos episódios passados, é usado como testemunha de que o jornal, mais uma vez, se colocava “a serviço do Brasil," ${ }^{4}$ exercendo também o papel de fazedor de história, a exemplo dos argumentos utilizados em 1964. A partir daí, para o jornalista, a Folha assumiria o lugar central na resistência ao regime militar. A graça anistiante começava a ganhar valor de amnésia pública e as ações do passado mudavam de significado para se adequar ao novo papel que o jornal se propunha. Ao se referir ao período que vai de 1962 a 1974, (Silva, 2005, p. 73, 74) avaliava:

Nesse período, não houve tempo para preocupações com o jornal em si. Todos os esforços de concentravam no saneamento financeiro da empresa [...] antes de poder pensar em organizar melhor o jornal, Frias teve que recuperá-lo economicamente. De 1962 a 1967, considerado a primeira fase de sua gestão, foi só disso que se tratou [...]

No período de 1968 a 1974, a preocupação essencial ainda não era a redação (Silva, 2005, p. 73, 74).

Em nenhum momento o autor menciona o golpe ou o apoio dado pela Folha ao episódio. Em um dos poucos trechos no qual faz uma menção direta a isso, limita-se a dizer que "no período histórico de 1967 a 1984, há que se levar em conta também os obstáculos políticos" (SILVA, 2005 p. 75), sem esclarecer quais seriam tais obstáculos. Tudo ocorre como se, a partir de um dado momento, o jornal simplesmente assumisse o lugar de protagonista em meio à apatia generalizada do País, personificando a imagem de uma liderança aglutinadora de todas as vozes contra o regime.

A obra de Lins da Silva pode ser compreendida como parte de um projeto, muito mais amplo que a mudança técnica-editorial implantada na Folha nos anos 80 . Significa, especialmente, a política de construção de uma nova identidade do jornal, que teve como ponto capital a formulação de uma nova memória. Ainda segundo o jornalista, “o jornal pressentiu a "abertura" política e investiu nela" (SILVA, 2005 p. 75). Contrariando o discurso racionalista sempre empregado para explicar as atitudes editoriais da Folha, o jornalista argumenta que será o “pressentimento” que levará o

\footnotetext{
${ }^{4}$ Apesar de o slogan já existir nas páginas das Folhas, é somente a partir de 1961, quando os três principais jornais do grupo são unificados como Folha de São Paulo, que passa a ser escrito na capa, permanecendo até os dias atuais.
} 
jornal a mudar tão drasticamente sua leitura sobre o acontecimento a partir de 1978. Nesse mesmo ano, foi produzido um documento interno com o objetivo de estabelecer os novos rumos editoriais do jornal para os anos subsequentes. Nele, são destacados três pontos fundamentais para a discussão. O primeiro deles é exatamente um esboço histórico no qual o jornal realiza uma breve análise sobre a história do Brasil, procurando analisar os motivos dos problemas brasileiros naquele momento.

Na análise, a história do jornal se mistura à do País, numa narrativa que intercala ambas em uma mesma matriz explicativa, cujo final, o tempo presente, se explica por uma longa cadeia de eventos que têm início com a colonização. Importante notar que a história é convocada para dar sustentação aos argumentos do grupo, de maneira a fazer crer que tudo se desenvolvera seguindo um curso linear de acontecimentos que culminaram com o inevitável colapso, que foi a tomada do poder pelos militares em 1964. Vejamos:

[...] Mas as contradições internas da sociedade são tão profundas e o liberalismo é uma solução tão pobre para resolvê-las que surge o colapso de 64. Forma-se então uma coligação de forças sociais, que oferece suporte político para que a alta burocracia estatal (especialmente o oficialato) opere o Estado a partir de uma proposta desenvolvimentista antiliberal e antidistributiva. Essa gestão pública responde a uma necessidade histórica de modernização do País e do próprio capitalismo. Mas ela se esgota ao cumprir a tarefa e o saldo que deixa atrás de si são distâncias sociais ainda maiores. O sistema autoritário [...] torna-se obsoleto (MOTA; CAPELATO, 1981, p. 241).

Os argumentos reforçam a tese de que não havia outro caminho a seguir, a não ser a imperiosa modernização do País implantada com o apoio de "uma coligação de forças sociais", uma necessidade histórica e inadiável, imposta por condicionamentos históricos e econômicos que "estão na própria trajetória histórica do jornal - que não pode ser negada e nas implicações do sistema capitalista em que vivemos - ao qual a Folha está submetida" (MOTA; CAPELATO, 1981, p. 240). Ao se apresentar como analista desse processo, passa a se situar em um local de emissor de opiniões e a reivindicar mudanças nessa sociedade: 
A partir dessas rápidas considerações históricas, propomos os seguintes pontos como formalização da tendência editorial da "Folha": (1) melhores condições de vida [...]; (2) organização de um regime democrático [...]; (3) liberdade de informação [...]; (4) fortalecimento dos organismos da sociedade civil [... ]; (5) distribuição mais equitativa da renda nacional $[\ldots]$; (6) apoio à livre iniciativa econômica[...] (7) submissão de toda a economia ao interesse social (...); (8) preservação da identidade nacional [... ]. (MOTA; CAPELATO, 2005, p. 241).

Na lógica apresentada pelo grupo, o episódio de 1964 foi um passo necessário para que se superassem problemas estruturais e históricos do País, na medida em que serviu para modernizá-lo; daí, não ser realizada nenhuma crítica à ocorrência em si, nem tampouco aos seus resultados gerais, uma vez que, até determinando ponto, parecia ter cumprido seu objetivo. A "coligação das forças sociais" é uma "totalidade" indefinida e amorfa, apresentada, assim, exatamente porque não importava pensar sobre quem se havia beneficiado com o estabelecimento de tais acontecimentos. O esboço histórico termina precisamente com a conclusão de que o esgotamento do presente deveria abrir a porta ao futuro, agora totalmente imprevisível para que se realizassem projeções sobre ele.

Na sequência, além de serem discutidos os “pontos indicativos", mencionados acima, sugere-se uma "avaliação do momento", quando o jornal analisa a conjuntura política e aponta abertamente o caráter autoritário do regime e, mais uma vez, destaca a necessidade de fechamento do ciclo: "Acreditamos que o regime político autoritário vemse tornando obsoleto na medida em que não atende mais aos interesses de setores importantes da população" (MOTA; CAPELATO, 1981, p.239). Para a Folha, não havia mais dúvida quanto ao encerramento do episódio e, assim sendo, passa a trabalhar fortemente para que isso ocorra em suas matérias e editoriais.

Ao comemorar seu aniversário de 60 anos, o jornal aproveita para reforçar sua posição, ao discorrer sobre o papel da imprensa na transição política, ressaltando que, acima de tudo, o jornalismo deveria funcionar como uma "espécie de termômetro das oscilações políticas e das tensões sociais" (OS CAMINHOS, 1981), uma vez que:

O termômetro jornalístico tem servido também para indicar os sentimentos que prevalecem na população, como ocorreu 
exemplarmente no fim do governo João Goulart. Naquela ocasião, a queda do presidente da república foi pontuada por contundentes editoriais, entre os quais merecem especial menção os do extinto Correio da Manhã que se incorporaram definitivamente à história do jornalismo no Brasil (OS CAMINHOS, 1981).

Curiosamente, ao mencionar os acontecimentos que precipitaram o golpe em 1964, o Grupo Folha se omite novamente como participante e apoiador do episódio, colocando-se como observador analista, situado num lugar de isenção em relação ao evento. Em sua reflexão, a imprensa desempenha uma função de valor quase universal, a velar pela sociedade, sendo a primeira a falar em nome dela. Ao fazer isso, realiza uma tentativa de despolitização de sua atuação, ao colocá-la em um lugar acima de todas as ideologias. Quando se refere a essa função, considerada primordial, o jornal se posiciona na narrativa apresentando a si próprio como espaço agregador de todas as opiniões e lugar de independência política para compreender os reais anseios dessa população. Num jogo que esconde e revela, direciona a imagem de si como sendo o modelo a representar o ideal de imprensa que construiu:

O registro da gama de tendências de opinião, da diversidade de interesses, das alternativas de análise da realidade política e social, quando equilibrada e pluralista como o que esta "Folha" procura fazer em suas colunas de colaboradores expressivos das diversas correntes da sociedade civil, parece vir ao encontro de uma expectativa profunda e de uma necessidade premente dos leitores (OS CAMINHOS, 1981).

Ainda sobre o Golpe, a menção ao Correio da Manhã funciona como uma espécie de memória-síntese da atuação da grande imprensa sobre o episódio. Primeiro, porque sustenta a justificativa de que todos acreditavam que em 1964 a deposição de João Goulart era necessária e inevitável. O editorial do Correio da Manhã do dia seguinte ao evento é contundente nesse aspecto:

A Nação não mais suporta a permanência do Sr. João Goulart à frente do Governo. Chegou ao limite a capacidade de tolerá-lo por mais tempo. Não resta outra saída ao Sr. João Goulart senão a de entregar o Governo ao seu legítimo sucessor. Só há uma coisa a dizer ao Sr. João Goulart: saia (FORA, 1964). 
Uma vez que todos souberam captar os anseios da população, justifica-se assim, a posição tomada pela grande imprensa em seus editoriais no dia seguinte ao Golpe, como pode ser demonstrado em algumas das principais manchetes daqueles dias:

De Norte a Sul, vivas à Contra-Revolução (Jornal do Brasil - Editorial $1^{\circ}$ abr. 1964)

Escorraçado. (Tribuna da Imprensa - 2 abr. 1964)

Ressurge a Democracia (O Globo - 4 abr. 1964)

São Paulo Repete 32 (O Estado de São Paulo $-1^{\circ}$ abr. 1964)

A tomada do poder pelos militares é apresentada como tendo sido desejo de toda a "população", como se chamasse o leitor a lembrar que todos queriam aquilo em 1964, responsabilizando-o também pelo episódio. Todavia, o segundo ponto importante nessa referência ao Correio da Manhã é o fato de ele se ter tornado um dos mais fortes espaços de denúncia ao governo militar poucos dias após o Golpe, passando a fazer, em suas matérias e editoriais, declarações diárias contra as arbitrariedades do regime, como uma série de matérias nas quais denuncia torturas e prisões ilegais pelo País já em setembro de $1964^{5}$.

Pode-se interpretar a alusão ao Correio da seguinte maneira: primeiro, a grande imprensa, e aqui se inclua a Folha, concedeu apoio aos militares porque soube compreender os "sentimentos que prevaleciam" entre a população contra João Goulart, mas logo em seguida, ao perceber que se instaurara ali um regime autoritário, voltou-se contra ele. O que o texto não diz é que durante quase todo o período os demais órgãos da imprensa ou se mantiveram ao lado do governo militar, a exemplo da própria Folha, ou se calaram, temendo represálias, como sofreu o Correio da Manhã.

A lembrança do jornal Correio da Manhã funciona como uma maneira de recalcar a lembrança sobre a atuação dos demais órgãos da imprensa e suas posturas frente ao episódio. Tenta homogeneizar as ações da grande imprensa na atitude de um veículo como se todos tivessem tido a mesma conduta. O jornal ainda chama a atenção para uma questão importante, ao afirmar que não é função da imprensa "conduzir a

\footnotetext{
${ }^{5}$ Algumas dessas matérias podem ser vistas em MOLICA, Fernando, et al. 10 reportagens que abalaram a ditadura militar. São Paulo: Record. 2005. Curiosamente, a única matéria da Folha mencionada no livro é uma denúncia de favorecimento do BNH a Delfim Neto, em 1982.
} 
história", e, numa resposta com a qual se antecipa às possíveis críticas futuras sobre seu apoio aos militares, afirma que:

[...] apesar das aparências a imprensa não faz governos nem desfaz regimes, mas registra os sentimentos, desejos e esperanças da população, além de manifestar suas alegrias e indignações; nem tampouco amolda a opinião, expectativa vã dos poderosos que mediante a propaganda e o controle da informação, provocam, ao contrário, o repúdio da opinião pública (OS CAMINHOS, 1981).

Omitindo as especificidades da participação de cada veículo frente ao Golpe e ratificando uma memória intencionalmente fragmentária sobre essas ações, ergue uma lembrança que recalca rapidamente as inúmeras nuances do longo e problemático processo de formulação desse episódio na cena pública e a importância da grande imprensa como formuladora de uma representação positiva do evento durante quase 20 anos. Fixa o olhar no presente, na transição, pois é ela que importa ao futuro e joga uma sombra sobre o passado, de forma a obliterar aquilo que não interessa lembrar na trajetória presente.

É assim que o jornal se sente plenamente à vontade em falar sobre a necessidade de "substituição de ideias" e liberdade de imprensa ainda em 1978, quando volta a escrever editoriais depois do episódio Diaféria. Liberdade que, segundo ele, foi, em vários momentos, mal-interpretada pela imprensa, que "muitas vezes empregou a liberdade de que dispunha no esforço de resguardar e ampliar interesses que, sobre serem minoritários e exclusivistas, eram antidemocráticos" (NOSSO, 1978).

Assim, progressivamente o jornal produziu o afastamento de sua imagem dos eventos desencadeados nos primeiros meses de 1964, colocando em ação estratégias com vistas a essa dissociação, sobretudo quando a reformulação da identidade do jornal passou a depender da lembrança de sua participação nessas ocorrências.

\section{"Esquecer é uma necessidade", ou o abrandamento do passado}

A tomada do poder pelos militares passou de "revolução de 1964" para “movimento de 1964" e, finalmente, para "regime autoritário", em fins dos anos de 1980. 
Tais mudanças fizeram com que o episódio se tornasse um artefato histórico plenamente configurado no conjunto das grandes ocorrências históricas do Brasil. Assim, houve uma progressiva deterioração da aura de episódio positivo e boa parte dos meios de comunicação do País foi pressionada a rever tanto suas posições, como suas previsões em relação a ele. Elementos que demonstram como a produção midiática, além de operar na escritura do acontecimento a cena pública, atua numa segunda formulação do evento, principalmente no trabalho de sua inscrição no tempo.

Se no final dos anos setenta o que impulsionava as ações era o debate sobre a abertura, a partir dos anos 80 a Folha passa a realizar uma política pública de esquecimento por substituição de eventos, quando são introduzidos outros episódios que acabam por eclipsar, quase totalmente, a relação da Folha com os acontecimentos de 1964 - dentre eles, destaco a abertura política e a campanha das Diretas. Assim, realiza um esquecimento administrado pela formulação de uma nova memória social - a partir de uma insistente campanha de autopromoção, responsável por fixar a imagem do jornal, nos anos 1990, como democrático, plural e apartidário.

Na nova fase narrativa, o "movimento de 64" é apresentado como episódio que se realizou praticamente à revelia da grande mídia e, consequentemente, sem seu apoio, o qual, sendo parte da sociedade civil organizada, sofreu seus efeitos negativos como a censura e a repressão, aspecto que fica claro nas palavras de Lins da Silva:

A opção pela forma de acumulação monopolista do capital feita à revelia da opinião pública a partir de 1964-1967 começou a revelar suas consequências práticas na segunda metade da década de 70 em diante [...]. Entre essas consequências, estavam, contraditoriamente, o fortalecimento do movimento sindical e de outros movimentos sociais e a aspiração inadiável por democracia representativa, como ficou claro entre 1974-1984 (SILVA, 2005, p. 105) (grifos meus).

Em um caráter profundo, tratava-se da busca de autoproclamação de uma nova função social para o veículo naquela conjuntura: adequar-se, por conseguinte, às novas exigências postas no cenário público de fins de 70. 0 desafio era o de não permanecer o mesmo, mas exatamente colocar-se como a diferença entre os demais 
veículos de comunicação. Imagem desenhada tempos depois e insistentemente narrada em suas páginas:

Por imagem pública devemos entender a unidade formada pelo corte ideológico das preocupações do jornal, pelo seu estilo editorial e pela sua fisionomia plástica. É preciso que essa unidade seja reconhecida pelos que lêem a Folha e vivida pelos que a fazem. Não devemos ambicionar as unanimidades [...] mas sim o reconhecimento da identidade pela diferença $[\ldots]$ (PROJETOS, 1985-1986)

$\mathrm{Na}$ formulação dessa diferença, intercalam-se novas expressões públicas da memória em sua relação com o episódio, processo que começa a se desenhar ainda em 1977, quando a manutenção do regime ditatorial começava a apresentar problemas cada vez mais graves. O "milagre econômico", carro-chefe da propaganda do governo Médici, e que durante todo o período era mencionado como justificativa para o duro sistema de repressão política e torturas, era denunciado em seus abusos. A ameaça do retorno da inflação era cada vez mais nítida, assim como um provável colapso energético.

A meta passou a ser, portanto, tornar a Folha um jornal rentável e competitivo como produto de circulação nacional. Para isso, aproveitou-se o momento no qual a questão da governabilidade e da cidadania eram pontos capitais a serem debatidos pela sociedade brasileira. Se a expansão do mercado em São Paulo, dominado pelo jornal $O$ Estado, ainda constituía um problema em princípios de 80, a participação de várias vozes dissonantes a se pronunciar em suas páginas ajudou a construir o reconhecimento político que tanto o veículo almejava para falar aos grupos que até ali se haviam posicionado contra o regime e a outros, ainda mais numerosos, que reivindicavam mudanças. É assim que passa a investir vigorosamente no potencial simbólico e, consequentemente, comercial, que viria com o processo de abertura. É o jornalista Mário Magalhães quem afirma:

Em janeiro de 1974, Golbery do Couto e Silva ${ }^{6},[\ldots]$ chamara Frias para uma reunião no Rio. Revelou que o novo governo iniciaria a distensão. Reafirmou sua obsessão com um "novo 9 de Julho" ${ }^{7}$, o temor de que houvesse uma rebelião paulista contra o poder federal nos moldes da

\footnotetext{
${ }^{6}$ Chefe da casa civil do presidente Ernesto Geisel.

${ }^{7}$ Dia em que teve início a chamada Revolução Constitucionalista de 1932.
} 
Revolução de 32. E disse que ao futuro governo não convinha apenas um jornal forte em São Paulo. A Folha era um jornal muito lido, mas de pouco prestígio e influência restrita. Era informativo, mas faltava-lhe densidade política. [... ] Numa reunião na casa de praia do "publisher", em Ubatuba, foi definido um "pacto", segundo Ruy Lopes. Ele conta ter participado de vários dias de discussão com Frias, Otavio Frias Filho, Cláudio Abramo e Boris Casoy. Ao final, decidiram, rememora o então editor-chefe, explorar ao máximo, jornalisticamente, as possibilidades da abertura (MAGALHÃES, 2001).

A partir de então, a lógica mencionada anteriormente por Lins da Silva foi colocada em pleno vigor. A abertura se tornou o grande capital político que possibilitou apresentar o jornal quase como o opositor histórico ao regime, como se não tivesse apoiado o golpe ou talvez como se o tivesse feito tão somente para representar os anseios da população naquele momento, assumindo, assim, condição de mais uma de suas vítimas. Nos anos 80 , termos como regime autoritário, censura, esquadrões de violência, pauperização entram definitivamente na narrativa cotidiana e o episódio passa a ser tratado como marco negativo a ser superado. Assim diz a Folha em seu projeto editorial de 1981:

Era natural, dessa maneira, que a Folha lançasse mão de todo e qualquer recurso que pudesse auxiliar na sua caminhada, ainda que precária e provisoriamente; era natural, por exemplo, que aproveitasse os ventos da abertura que sopravam já no período 1974-1978 para concentrar a maior parte de seus esforços na criação de impacto opinativo ("agora sim a Folha tem opinião", dizia-se com alguma frequência, pouco importa neste momento se acertada ou equivocadamente) que permitisse ao jornal alçar-se no conceito público (PROJETO, 1981).

O engajamento político é descrito como parte de um projeto maior que pretendia "alçar" o jornal ao primeiro plano no conceito público. Tanto a abertura política como a campanha das Diretas concedem ao jornal a possibilidade de elaborar para si outra narrativa de participação na história recente do País. Em pouco tempo, esses episódios se tornam o principal foco na tessitura de sua memória, fazendo com que parte do passado perca importância na formulação do novo papel social que se propõe exercer. Memória de um lado e esquecimento de outro, numa relação dialética e complementar, efetivada pela função narrativa. Portanto, interessam, aqui, menos os meandros desse 
engajamento e mais a maneira como ele será lido e interpretado em sua relação com a memória do grupo, uma releitura que começa a ser elaborada já em princípio dos anos oitenta, chamada pelo jornal de "a década da incerteza":

A abertura de uma nova década configura um momento especialmente propício à reflexão. É como se pudesse recomeçar tudo do marco zero. Mas, na verdade, o tempo não volta atrás. Por essa razão, tornam-se oportunos os balanços nessas épocas, quando se criam ocasiões para projetar o futuro. Futuro sombrio. De resto. (A DÉCADA, 1980)

Percebamos que o jornal coloca seus leitores diante de um novo ciclo narrativo e acontecimental. Como o fizera em 1964, leva-os a um estado de espera e, embora chame a atenção para o fato de que "o tempo não volta atrás", situa-os diante de um presente que figura como um tempo de angústia frente à imprevisibilidade de futuro. Tempo "sombrio", nas palavras do jornal, como se todas as respostas somente pudessem ser dadas pelo devir em "um mundo extremamente dividido, incerto e inseguro" (A DÉCADA, 1980), e para o qual seria impossível realizar projeções sensatas.

O passado representa um tempo de lições amargas e, ao se referir a ele, o jornal vai buscar exemplarmente o que considera os grandes momentos de crise da humanidade, como que prenunciando uma fase de desesperança e mal-estar que se iniciava naquele momento. A referência é feita a lugares muito mais distantes, no tempo e no espaço, para tentar construir uma explicação de longo prazo para os problemas enfrentados pelo Brasil, narrativa que a princípio esmaece o passado recente do País. Revoluções como a Francesa e a Industrial, crise dos sistemas coloniais, guerras mundiais, falências das grandes potências ocorridas em 1929, Comuna de Paris, dentre outros eventos considerados de caráter universal, são mencionados até bruscamente cortar a narrativa, com o que chama o leitor a se situar em plena década de 70 no Brasil do século $\mathrm{XX}$ :

Após tantos exercícios de planejamento, tanta fabricação de "milagres" e muita teoria econômica, chega-se à trágica constatação de que o mundo deve conviver com a crise. A crise econômica, mas também a crise das teorias que criaram os mitos de abastança na última década. Sobretudo no Brasil. (A DÉCADA, 1980) 
Percebamos que todas as ocorrências deflagradas nos anos 60 são omitidas na tessitura. A crise toma como marco explicativo a década posterior, mais precisamente, os últimos cinco anos. Lembro que até 1975 o jornal comemorava efusivamente as conquistas econômicas do primeiro decênio do Golpe. Todavia, mesmo que não seja mencionado, o episódio é o não-dito sempre presente no texto, pois, justamente ao dar o salto para a década de 70, o discurso é o da decepção com um futuro de expectativas não realizadas.

Na verdade, o episódio continua projetado na narrativa, posto que todos os principais elementos de crítica na matéria se relacionam com o regime militar. Mas para fazê-lo, o jornal realiza um recorte preciso sobre os problemas que a nação enfrentava naquele momento. Talvez resida exatamente aí o sucesso da estratégia narrativa, que, embora nos leve a nos interrogar sobre o passado, antecipa-se em dar as respostas, tentando conduzir a maneira como ele deveria ser visto:

Dos anos 70 herdou-se, por outro lado, um fardo bastante pesado. Podem ser considerados talvez os anos mais difíceis da História do Brasil. Regime autoritário fechado, luta armada, crescente pauperização (falemos claro: miséria), inflação acelerada na última fase, dívida externa imensa, deterioração do ensino em todos os níveis, ampliação da violência dos esquadrões de linchamentos. (...) viver passou a ser algo efetivamente perigoso.(...) O capitalismo selvagem exigia silêncio (...) a sociedade civil acordou e se descobriu débil, entorpecida, conformista. Anos de cooptação, morna vivência à sombra do poder, transformaramna em um seguimento dócil da ordem dominante (A DÉCADA, 1980)

A crítica ácida e contundente do jornal nada lembra a Folha de poucos anos antes $^{8}$. Como se estivesse também a realizar uma crítica sobre si, parece levantar-se do estado de entorpecimento no qual se encontrava, passando a bradar contra todos os

\footnotetext{
${ }^{8}$ Vejamos o Editorial do dia 30 de março de 1975: "Ao completar seu $11^{\circ}$ aniversário, a Revolução de 31 de março se apresenta aos olhos da nação dentro de um processo evolutivo perfeitamente consonante com os propósitos que a justificaram [...]. A normalidade democrática em nome da qual se levantou $o$ país em 1964 configurando a finalidade primordial da Revolução que visa atingi-la constitucionalmente em toda sua plenitude, não deve, entretanto, servir de pretexto para contestações, revanches ou inadmissíveis retornos a um deprimente passado. [...] Nenhum brasileiro, por certo, desejaria voltar à agitação e ao desgoverno que caracterizaram aqueles dias de confusão e tumulto por que passamos há 11 anos" (Folha de São Paulo, Editorial, 30 mar. 1975, 3).
} 

se apresenta no texto, principalmente quando destaca que foi à "margem do regime que se desenvolveram muitas forças vivas e críticas”. Em seguida, destaca o papel desempenhado por instituições como a OAB, a CNBB, os sindicatos dos jornalistas, e chama a atenção em especial para o fato de que foi graças "à imprensa, sobretudo, a que conseguiu se manter independente nessa década" que muito se deve ao “estabelecimento de um espaço crítico" (A DÉCADA, 1980) contra os militares. Esse é um elemento capital na nova chave de reformulação da identidade do jornal: o destaque à sua "independência" e pretensa isenção, tanto em relação ao governo como a outros veículos de comunicação. Não por acaso, coloca-se quase como veículo isolado a iniciar a luta pela redemocratização do País.

Dessa forma, pode-se compreender o percurso de um grande projeto que soube dosar exemplarmente memória e esquecimento na construção da imagem pública desse grupo. Um esquecimento que, como disse anteriormente, não se deu pelo apagamento de rastros, pois o jornal em nenhum momento vem a público negar seu apoio aos militares e ao regime por longos anos, mas que se sustentou na função seletiva da narrativa, para construir uma poderosa memória política sobre si, tão forte, que sequer foi questionada muitos anos após a abertura política, ao contrário de outros grandes veículos de comunicação alinhados ao regime em 1964․ Uma tessitura que conseguiu fazer do jornal, possivelmente, um do poucos exemplos quase consensuais no que diz respeito à legitimidade da reflexão política no País. O projeto Folha, organizado nos anos 80, foi muito mais um projeto de reconstrução de memória do que de reformulação técnico-editorial.

Um esquecimento produzido pela substituição da memória de outros eventos, construídos como novos marcos identitários. O jornal buscou outras formas de narrar-se, através de deslocamentos e supressões, ora realçando atitudes posteriores, ora jogando

\footnotetext{
${ }^{9}$ Um dos exemplos mais claro disso foi a atuação da Rede Globo que recentemente veio a público se desculpar pelo fato de ter apoiado os militares em 1964.
} 

tragédias daqueles dias, sendo mais um a sofrer suas consequências. Deparamo-nos, assim, com uma situação bastante peculiar: além de não poder escapar de uma reflexão sobre o fracasso da política social e econômica, resultado dos anos da ditadura, o jornal teve ainda que "abrandar" sua atuação nesse período. Necessitou se equilibrar entre uma memória que o vinculava diretamente aos militares e um trabalho de esquecimento que Ihe possibilitasse tornar-se porta-voz da democracia.

Um paradoxo, aparentemente de difícil resolução, que começou a ser enfrentado no curso daqueles dias com o engajamento do grupo no processo de abertura. Com isso, nota-se como a abertura política e, posteriormente, a campanha das Diretas-Já foram instrumentalizados para se reverterem em estratégias para seu esquecimento sobre o apoio dado ao golpe em 1964. Mesmo depois, quando o episódio volta a ser relacionado à Folha ${ }^{10}$, tem um peso muito menor em sua história, diante do que representam a abertura e a campanha das diretas na construção de sua memória.

Isto pode ser constatado nas palavras do jornalista e cientista político André Singer, em 2002, segundo o qual o processo de constituição do projeto Folha foi produto da abertura, assim como "influenciou na abertura política, ajudando para que ela culminasse numa verdadeira transição para a democracia” (SINGER, 2003, p. 53). A narrativa sobre o processo de abertura se confunde com a história da Folha, apresentada como uma das protagonistas e impulsionadoras do processo. Se os anos 80 são tomados como o começo de um novo ciclo político e social para o País, representam também a efetivação do prestígio político da Folha no cenário nacional.

O espaço dado a colaboradores de perspectivas tão diversas como Fernando Henrique Cardoso, Miguel Arraes, Jarbas Passarinho, Jorge Boaventura, Boris Casoy, Alberto Dines, Paulo Francis, dentre outros, concedeu ao jornal força e reconhecimento

\footnotetext{
${ }^{10} \mathrm{Em}$ poucos momentos, ao longo das ultimas décadas, a Folha teve que enfrentar questionamentos sobre seu alinhamento com os militares. É provável que o mais visível deles tenha sido em 2009, com o desencadear de críticas relacionadas ao Editorial que trata o período como "Ditabranda".
} 
político no âmbito nacional, nas palavras do seu atual diretor de redação, Otávio Frias Filho: "a Folha viveu a sua Primavera de Praga” (MAGALHÃES, 2001).

As opções públicas que o jornal passa a assumir podem ser explicadas ainda por outros aspectos. Um deles, sem dúvida bastante relevante, é a postura do jornal em se assumir como um empreendimento de mercado e, portanto, submetido à necessidade de se adequar às mais diversas conjunturas a fim de se manter competitivo enquanto tal. Condição em grande parte planejada e articulada pelo jornal, não é por acaso que já em 1981 se autoreferencia como um dos mais importantes do País, como pode ser observado em seu projeto editorial daquele ano:

[...] O jornal representa atualmente muito mais do que já representou através de sua atuação e imagem públicas no passado. Ao seu redor, surge um crescente consenso de que este é, de fato, um jornal independente, confiável naquilo que publica e cujas atitudes devem ser permanentemente levadas em consideração. Vem escrevendo de modo cada vez mais nítido o seu papel real na cena política, preenchendo a função de um órgão liberal-progressista, [...] preocupado com a necessidade de introduzirmos reformas pacíficas, mas, profundas no capitalismo brasileiro, destinadas a solucionar os problemas sociais mais graves e criar convivência social estimável para a maioria e aceitável para as minorias (PROJETO, 1981).

A citação ressalta a relação "estreita entre memória declarativa, narratividade e testemunho, representação figurada do passado histórico" (RICOEUR, 2007, p. 455). No processo de ideologização da memória através da narrativa, percebe-se como o jornal joga com efeitos de variação na tessitura de sua nova identidade. Sendo assim, as estratégias de esquecimento são sutilmente inseridas de maneira a desfocar elementos identitários anteriores. Do passado, sabemos somente o que interessa para o entendimento sobre a posição do periódico no presente, o que pode ser resumido num esforço de sua afirmação no cenário nacional a fim de se tornar "um jornal independente, confiável”. 


\section{Considerações finais}

Em princípios dos anos oitenta, além da luta pela democracia e o fim da ditadura, o que estava em jogo era também um trabalho de formulação de sentidos, tanto sobre o passado como sobre o presente. Sairiam vitoriosos aqueles que melhor soubessem lidar com as variadas articulações da memória e esquecimento. Constatou-se ainda uma grande resistência no enfrentamento das questões sobre a culpabilidade ou a criminalização de torturas, prisões ilegais e desaparecidos políticos como ponto de pauta das discussões sobre o período militar, o que expõe o caráter comandado desse esquecimento. Na medida em que houve uma clara tentativa de apagamento dessas questões, impossibilitou-se que o debate de versões criasse condições para "uma reapropriação lúcida do passado" (RICOEUR,2007, p. 462).

Ao se aproximar assim da amnésia, a anistia põe a relação com o passado fora do campo em que a problemática do perdão encontraria com o dissensus, seu justo lugar. [...] Tal mandamento equivaleria a uma amnésia comandada. Se esse obtivesse êxito [...] a memória privada e coletiva seria privada da salutar crise de identidade que possibilita a apropriação lúcida do passado e de sua carga traumática (RICOUER, 2007, p. 462.).

Procurei apresentar aqui como o jornal Folha de São Paulo lançou mão de uma estratégia de esquecimento comandado sobre sua atuação relativamente ao Golpe de 1964. Assim como ele, outros veículos também construíram sua própria versão, mais ou menos aceita, sobre sua participação nos acontecimentos daquele ano. Para que seu projeto de reformulação de identidade tivesse pleno êxito, foi necessário elaborar uma argumentação que suprimisse um conjunto significativo de fragilidades políticas e colocasse em evidência outros eventos. Para o jornal, as novas ocorrências desencadeadas com a abertura funcionaram como acontecimentos deflagradores de uma identidade desejável, tanto política como comercial. Como memória, serviram para vincular o jornal à lembrança nacional da redemocratização e o fim do período ditatorial. Como esquecimento, serviram no conjunto de suas argumentações para reescrever sua memória, agora distante, em relação ao Golpe Militar de 1964. 
Os anos noventa significaram a consolidação da Folha no cenário nacional como um dos grupos de mídia de maior força no País, destacando também seu reconhecimento entre políticos e intelectuais como canal da democracia, o que atesta o sucesso na elaboração de sua nova identidade. Quando 1964 volta às páginas do jornal em suas efemérides, torna-se objeto de espetacular apelo midiático que acaba por desencadear uma frenética demanda de produtos que têm como base a retomada de uma política de memória sobre ele. Nesse novo momento, o jornal também atua de maneira significativa como urdidor do passado. Sob vários aspectos, o acontecimento midiático e histórico no qual se configurou o Golpe de 1964 serve para ajudar a entender o que o jornal Folha de São Paulo é hoje. Se, inicialmente, sua associação e conivência com o governo militar the renderam estabilidade e possibilidade de crescimento mercadológico, duas décadas depois, foi o elemento que lhe permitiu construir a imagem como veículo plural e apartidário, justamente por se apresentar como seu opositor. Para a Folha de S. Paulo, um trabalho de esquecimento comandado, que se organizou não pela destruição dos rastros do passado, mas por uma memória encobridora, uma ação forte de reformulação identitária que alçou o jornal ao primeiro plano dos debates políticos do País. Exatamente pelo poder de suas narrativas, o grupo soube capitalizar esse acontecimento como importante referencial para a construção de sua própria memória.

\section{Referências}

ABRAMO, Cláudio. A regra do jogo. São Paulo: Cia das Letras, 1988.

A DÉCADA da incerteza. Folha de S. Paulo - Editorial. $1^{\circ}$ Caderno, p. 2, São Paulo: Folha da Manhã, $1^{\circ}$ jan. 1980 , p.2. (Microfilme disponível na Fundação Biblioteca Nacional- Setor de Microfilmagem).

COLUNA. Lourenço Diaféria. - Ilustrada, $2^{\circ}$. Caderno, Folha de São Paulo, Folha da Manhã, p. 44, 16 de set. de 1977. ((Material disponível Fundação Biblioteca NacionalSetor de Microfilmagem). 
DÁVILA, Sergio. O dia em que Jango começou a cair. Opinião - Folha de S. Paulo. 13 de março de 2004. Especial Golpe Militar 40 anos 1964-2004. Disponível em: http://www1.folha.uol.com.br/fsp/brasil/fc1303200420.htm >. Acessado em: 06 de set. de 2010.

DIAFÉRIA, Lourenço. Herói. Morto. Nós. Folha de S. Paulo, 1 set.1977, Folha 80 anos, Folha Online, cap. no end. http://www1.folha.uol.com.br/folha/8oanos/tempos_cruciais02a.shtml, Acessado em 16 out. de 2013.

DOCUMENTO interno do conselho editorial da Folha - 1978. In: MOTA, Carlos Guilherme e CAPELATO, Maria Helena. História da Folha de São Paulo (1921-1981). São Paulo: IMPRES, 1980, p. 239.

FOLHA DE. S. PAULO. 20 textos que fizeram a história. São Paulo. Folha de São Paulo, $1^{\text {a }}$. 1991. p. 7.

FOLHA DE S. PAULO. São Paulo: Folha da Manhã. 04 de mar. 1964a. Capa. (Material disponível Fundação Biblioteca Nacional- Setor de Microfilmagem).

FOLHA DE S. PAULO. São Paulo: Folha da Manhã. 13 de mar. 1964b. Capa. (Material disponível Fundação Biblioteca Nacional- Setor de Microfilmagem).

FORA! editorial. Correio da Manhã. Rio de Janeiro, $1^{\circ}$ abr. 1964. p. 02 (Microfilme disponível na Fundação Biblioteca Nacional- Setor de Microfilmagem).

LIMA, Hermes. Sociedade e arbítrio político - Tendências/Debates, $1^{\circ}$. Caderno, Folha de São Paulo, Folha da Manhã, 22 set.1977 (Fundação Biblioteca Nacional - Setor de Microfilmagem).

MAGALHÃES, Mario. Militares ameaçam suspender circulação - Folha apoiou o regime de 64, mas se engajou na redemocratização nos anos 70. 2001, Folha de São Paulo. Folha 80 anos. Folha Online. Disponível

em: http://www1.folha.uol.com.br/folha/8oanos/tempos_cruciais-02.shtml. Acesso em: 27 set. 2007.

MOTA, Carlos Guilherme; CAPELATO, Maria Helena. História da Folha de São Paulo (19211981). São Paulo. Impres, 1981.

MOLICA, Fernando. 10 reportagens que abalaram a ditadura. Rio de Janeiro/São Paulo. Record, 2005.

NÓS - Folha de S. Paulo - Editorial. $1^{\circ}$ Caderno, Folha de São Paulo, Folha da Manhã, p. 02, 17 de set. de 1977. ((Material disponível Fundação Biblioteca Nacional- Setor de Microfilmagem). 
NOSSO direito e nosso dever. Folha de S. Paulo. São Paulo: Folha da Manhã, 7 maio 1978. Editorial. $1^{\circ}$ Caderno, p.2. (Microfilme disponível Fundação Biblioteca Nacional - Setor de Microfilmagem).

O BRASIL Continua - Folha de São Paulo, Editorial. $1^{\circ}$. Caderno; São Paulo Folha da Manhã, 03 de Abr. 1964, p3. (Microfilme disponível na Fundação Biblioteca Nacional - Setor de Microfilmagem)

O CAMINHO da Transição. Folha de S. Paulo. São Paulo: Folha da Manhã, 7 set. 1980, Editorial. p. 2 .

OS CAMINHOS da transição. Folha de S. Paulo, Editorial. $1^{\circ}$. Caderno; São Paulo: Folha da Manhã, 19 fev. 1981, p.2. (Microfilme disponível na Fundação Biblioteca Nacional - Setor de Microfilmagem).

PRESO Lourenço Diaféria. Folha de S. Paulo, (Capa). $1^{\circ}$. Caderno; São Paul: Folha da manhã, 16 de set. de 1977. (Microfilme disponível na Fundação Biblioteca Nacional- Setor de Microfilmagem).

PRIMEIRO CADERNO. Folha de S. Paulo, São Paulo: Folha da Manhã, 04 de mar., 1964a. p.3. (Microfilme, disponível Fundação Biblioteca Nacional - Setor de Microfilmagem).

PRIMEIRO CADERNO. Folha de S. Paulo, São Paulo: Folha da Manhã, 05 de mar. 1964b. p.2. (Microfilme, disponível Fundação Biblioteca Nacional - Setor de Microfilmagem).

PRIMEIRO CADERNO. Folha de S. Paulo, São Paulo: Folha da Manhã, 06 de mar. 1964C. p.4. (Microfilme, disponível Fundação Biblioteca Nacional - Setor de Microfilmagem).

PRIMEIRO CADERNO. Folha de S. Paulo, São Paulo: Folha da Manhã, 08 de mar. 1964d. p.3. (Microfilme, disponível Fundação Biblioteca Nacional - Setor de Microfilmagem).

PRIMEIRO CADERNO. Folha de S. Paulo, São Paulo: Folha da Manhã, 11 de mar. 1964e. p.3. (Microfilme, disponível Fundação Biblioteca Nacional - Setor de Microfilmagem).

PROJETOS Editoriais 1985-1986 - Depois da Democratização. Folha On-Line. São Paulo. Disponivel em: http://www1.folha.uol.com.br/folha/circulo/proj_85_1parte.htm. Acesso em: 26 set. 2007.

PROJETO Editorial 1981: um ponto de passado e de futuro. Folha On-Line. São Paulo. Disponível em:http://www1.folha.uol.com.br/folha/circulo/proj_81_2parte.htm. Acesso em: 26 set. 2007.

RICOEUR, Paul. A Memória, a história, o esquecimento. São Paulo: Unicamp, 2007. 
RICOEUR, Paul. Événement et sens. Raisons Pratiques, n.2 l'événement en perspective, Paris : Ecole des Hautes Études en Sciences Sociales. 1991.

SILVA, Carlos Eduardo LINS da. Mil dias: seis mil dias depois. São Paulo: Publifolha, 2005.

SINGER, André et al. Políticas de antecipação: a Folha na abertura democrática. In: Um país aberto: reflexões sobre a Folha de São Paulo e o jornalismo

contemporâneo. São Paulo: Publifolha. 2003, p. 53. 